\title{
Improvement of Mathematic Connection and Communication Ability at Danau Paris State 1 High School Through Contextual Learning
}

\author{
Adi Semarto Berutu* Izwita Dewi Mukhtar \\ Department of Mathematics, Science Faculty, State University of Medan, Jl. William Iskandar Ps. V, Kenangan \\ Baru, Sumatera Utara Indonesia
}

\begin{abstract}
This study aims to: 1) To find out whether the increase in mathematical connection abilities of students who get contextual learning is higher than students who get ordinary learning. 2) To find out whether the increase in mathematical communication skills of students who get contextual learning is higher than students who get ordinary learning. 3) To see whether there is an interaction between the learning approach used with the students 'initial abilities to the students' mathematical connection abilities. 4) To see whether there is an interaction between the learning approach used with students 'initial abilities to students' mathematical communication skills. The subjects in this study were students of class XII IPA-1 as an experimental class and students of class XII IPA-2 as a control class at SMA Negeri 1 Danau Paris. The results showed that: 1) Increased mathematical connection ability of students who received contextual learning was higher than students who obtained ordinary learning. 2) Improvement of mathematical communication skills of students who get contextual learning is higher than students who get ordinary learning. 3) There is no interaction between the learning approach and initial mathematical ability to improve students' mathematical connection abilities. 4) There is no interaction between learning approach and initial mathematical ability to improve students' mathematical communication skills.
\end{abstract}

Keywords : mathematical connection skills, mathematical communication skills, contextual learning

DOI: $10.7176 / \mathrm{JEP} / 11-21-05$

Publication date:July $31^{\text {st }} 2020$

\section{Introduction}

With reference to the five NCTM capability standards, the purpose of mathematics learning in Permendiknas No. 22 of 2006 (Ministry of National Education 2006: 346) essentially includes (1) Connections between concepts in mathematics and their use in problem solving, (2) Reasoning, (3) Problem solving, (4) Communication and representation, and (5) Affective factors . In both documents, communication skills and mathematical connections are strategic abilities that are the goals of mathematics learning, so these two abilities are very important to be trained to students in school, especially in mathematics.

So students can see the connection between concepts in mathematics, then when introducing new concepts in mathematics learning, it is necessary to pay attention to concepts or materials that have been studied by students before and at the same time to remind them again. Therefore, in order for students to be more successful in learning mathematics, it must be given many opportunities to see the connections. This is in line with the opinion of Hariwijaya (2009: 43) which states that "learning mathematics will be more meaningful with the emphasis on the relationship between mathematical concepts with everyday life or other scientific disciplines".

Given the importance of this mathematical connection ability of these students, so these ability skills must be built and taught and trained to students so that these abilities can be utilized in dealing with problems of daily student life. However, in reality students have not yet realized the importance of mathematical connections so they still assume that each concept in mathematics stands alone and is not related to other mathematical concepts. Some research results show that students' mathematical connection ability is still low, one of them, Ruspiani's research results (2000: 120) which shows the average value of mathematical connection ability of middle school students is still low, namely less than 60 on a score of 100 (22.2\% for connections mathematics on other subjects, $44 \%$ for connections in other fields of study, and $67.3 \%$ for mathematical connections in everyday life).

Besides developing mathematical connection skills, developing students' mathematical communication skills is also important to be trained by the teacher in learning mathematics, because mathematics is also known as language. Suriasumantri (2012: 42) argues that "mathematics is a language that symbolizes a series of meanings from the statement to be conveyed". Mathematical symbols are artificial new meaning after a meaning is given to them, without it mathematics is only a collection of axioms, definitions, theorems, and formulas that are less meaningful.

Mathematical communication is the ability of students to communicate which includes the activities of using the skills of reading, writing, listening, analyzing, interpreting, and evaluating ideas, symbols, terms, and mathematical information that are observed through the process of listening, presenting, and discussing. Communication is a way of sharing ideas and clarifying connections, so students need to be trained intensively so 
students are actively involved during learning. Students must be accustomed to giving arguments to each answer and giving responses to answers given by others, so that what is being learned becomes meaningful to him. This is in line with the opinion of Hariwijaya (2013: 16) which states that "communication skills are very necessary to trace and describe the construction of analytical solutions or logical translation of mathematical problems that arise". If students have the communication skills will certainly make an in-depth understanding of the mathematical concepts students learn, this means the teacher must strive to encourage students to be able to communicate mathematically well. However, the facts on the ground that in learning so far the teacher is not able to create an atmosphere that can improve mathematical communication skills so that the communication skills of students in mathematics are very limited only to short answers to all problems raised by the teacher.

One of the causes of the low mathematical connection and communication skills of students is because our education is still weak in the learning process in the classroom, for example students can work on math problems provided, but when asked how to get results, students become confused and have difficulty in explaining. In addition, students often find errors in expressing mathematical notation, symbols and terms. This is in line with the opinion of Kusumawati (2012: 129) which states:

"Some things that cause students' learning difficulties, namely: (1) Mathematical learning is still abstract without linking mathematical problems with life; (2) Student learning motivation is still weak because of ignorance of the learning objectives; (3) Students do not dare to express ideas or ideas to the teacher; and (4) Teachers are still dominant in learning ".

According to Polla (1999: 71), "in general the quality of mathematics learning is considered low especially in Indonesia, one of the causes is that the communication aspect has not been emphasized". As a consequence, we must make some efforts to apply aspects of communication in mathematics learning. The research results Wono Setyabudhi, a mathematics lecturer from the Bandung Institute of Technology (in Napitupulu 2012: 62) states that "learning mathematics in Indonesia still emphasizes memorizing formulas and calculating ". In fact, the teacher is authoritarian with his belief in mathematical formulas or knowledge that already exists. Apart from learning factors, there are also other factors that can contribute to students 'mathematical communication and communication skills, namely the students' initial mathematical ability (KAM) group. Mathematical initial ability is an important prerequisite that students must have in order to be able to follow the lesson smoothly. A hierarchical mathematical structure requires a high initial mathematical ability to be ready to learn the next material, as Uno said (2011: 131) that "in learning mathematics must be done hierarchically". Students must first understand the prerequisite material so as not to have difficulty in learning the next material. Early mathematical abilities can be classified into 3 levels, namely low, medium and high (Lambertus et al, 2014: 605). Although the initial abilities of these students are so important, but based on information obtained from mathematics teachers in SMA Negeri 1 Lake Paris, these early mathematical abilities are rarely considered. Therefore, this study will also examine the interaction between students 'initial mathematical abilities and learning approaches to improving students' mathematical connection abilities and mathematical communication skills.

One learning approach that is thought to be able to be used to assist students in developing their mathematical connections and communication skills is the contextual approach because learning with a contextual approach encourages students to play an active role in finding the relationship of material learned with real life so that learning becomes more meaningful and real. Siregar (2014: 117) states "the contextual approach is a learning concept that helps teachers link material taught with real situations students and encourage students to make connections between the knowledge they have and their application in their lives as family and community members". Contextual learning helps students find meaning in their learning by connecting and linking mathematical material with the context of their daily lives, they can build individual interests to work alone or in groups in order to achieve meaningful goals by linking teaching material and the context of daily life. So that contextual learning is closely related to students' mathematical connection abilities.

In contextual learning students are actively required. Teachers must be able to create a student-centered learning environment and students with all the potential they have will try to construct their own understanding with the help of the teacher as a guide and guide. Nurhadi (2004: 8) states that "The fundamental definition of contextual learning is the concept of learning in which the teacher brings the real world into the classroom and encourages students to make connections between the knowledge they have and their application in their daily lives, while students gain their knowledge and skills. from a limited context, little by little, and from the process of constructing itself, as a provision to solve problems in his life as members of the community ". In a learning environment like this, interaction or communication between students and teachers, teachers and students and students and other students will often occur. This shows that between contextual learning with student communication has a close relationship. Thus contextual learning is thought to improve students' mathematical connection and communication skills.

From the description above so that educational goals can be achieved, it is deemed necessary to examine the improvement of students' mathematical connections and mathematical communication abilities with the title: "Improvement of Mathematical Connection and Mathematical Communication Capabilities of SMA Negeri 1 
Lake Paris Students Through Contextual Learning".

\section{Methods}

\section{Research Pattern}

This study uses a quantitative approach. The quantitative approach is carried out in the form of a quasi experiment to see students' connection skills and mathematical communication skills by comparing the contextual learning model with the normal learning model.

\section{Participants}

The subjects in this study were students of class XII IPA-1 as the experimental class and students of class XII IPA2 as the control class at SMA Negeri 1 Lake Paris.

\section{Data Collection Technique}

This experimental research consisted of 3 stages: first, the preparatory stage. At this stage, it starts with an introduction that is used to get the problem identification, problem formulation and literature needed. So it can be determined which research tools are used Second, the preparation phase begins with a research tool consisting of (1) learning approaches, (2) learning tools such as lesson plans, teaching materials and LAS, (3) research instruments. Then the control class and the experimental class were selected as research subjects. The learning device before being tested on research subjects is first validated by competent experts.

Third, the stage of implementation and data analysis. At this stage begins by giving a pretest to students, then in the experimental class action is carried out in the form of a learning model that is a contextual learning model and normal learning in the control class. Then the observations of both teacher and student activities were carried out on both learning models and at the end of the study tests were given on students' mathematical communication and communication skills. At the data analysis stage, the test data for mathematical connection and communication skills with two learning models are analyzed quantitatively.

\section{Validity and Reliability}

Validation of learning devices and instruments aims to obtain valid learning instruments and research instruments that are suitable for use in research. Learning devices and research instruments are validated by 5 experts. Based on the results of the learning device validation it was found that learning devices were good for use in learning. the validation of the research instruments was carried out statistical tests (empirically) to see the validity, reliability so that the validity of the research instruments was getting better.

\section{Data Analysis}

Data analysis in question is descriptive statistical analysis and inferential statistical analysis. Descriptive analysis aims to provide an overview of students' initial mathematical ability (KAM) data, students' mathematical connection ability data and students' mathematical communication skills data before and after treatment in the experimental class and the control class. Inferential analysis aims to statistically test the hypothesis The students' mathematical connection ability test aims to obtain quantitative data in the form of a mathematical connection ability score arranged based on indicators of mathematical connection ability. The test of students' mathematical communication skills in the form of pretest and posttest. The topic of the test was linear programming. The questions in this test are arranged in the form of description items. The preparation of this problem refers to Ansari's research (2009: 52) which requires students to give answers in the form of drawing (mathematical), mathematical expressions (mathematical expression), and write answers in their own language (written texts).

\section{Result and Discussion}

\section{Description of Students' Early Mathematical Ability (KAM)}

The Beginning Mathematics Ability Test (KAM) is given to students in the experimental and control classes with the aim of grouping students into high, medium and low ability groups. From the results of the KAM test the average and standard deviation are calculated. A summary of the calculation results is presented in Table 4.1. following.

Table 4.1. Average and Standard Deviation of KAM Student Data

\begin{tabular}{|l|c|c|}
\hline \multicolumn{1}{|c|}{ Statistics } & Experimentation Class & Control class \\
\hline Average & 71,33 & 68,50 \\
\hline Standard Deviation & 16,66 & 18,53 \\
\hline
\end{tabular}

It can be seen that the standard deviation of the control class is 18.53 higher than the standard deviation of the experimental class by 16.66. This means that the deviation of the KAM score of students against the average in the control class is greater than the KAM deviation of students in the experimental class. 


\section{Description of Improving Students' Mathematical Connection Ability.}

The amount of improvement in students' mathematical connection ability in the experimental class and the control class is determined by the Normalized Gain index formula (g). After obtaining the Normalized Gain (g) index data, the average and standard deviation is calculated. A summary of the results is presented in Table 4.2. following.

Table 4.2. Average and Standard Deviation of N-Gain Index Data for Students' Mathematical Connection Ability

\begin{tabular}{|l|c|c|}
\hline \multicolumn{1}{|c|}{ Statistics } & Experimentation Class & Control class \\
\hline Average & 0.45 & 0.26 \\
\hline Standard Deviation & 0.19 & 0.13 \\
\hline
\end{tabular}

Based on Table 4.5. it can be seen that the N-Gain index of experimental class mathematical connection ability is 0.45 higher than the N-Gain index of control class connection ability that is equal to 0.26 . This shows that the increase in students 'mathematical connection abilities given contextual learning is higher than the increase in students' mathematical connection abilities that are given regular learning. In addition, the standard deviation of the N-Gain index in the experimental class was 0.19 , slightly higher than the standard deviation of the N-Gain index in the control class, which was 0.13 .

1) Description of Improving Students' Mathematical Communication Skills.

The amount of improvement in students' mathematical communication skills in the experimental class and the control class is determined by the Normalized Gain (g) index formula. After obtaining the Normalized Gain (g) index data, the average and standard deviation is calculated. A summary of the results is presented in Table 4.10. following.

Table 4.3. Average and Standard Deviation of N-Gain Index Data for Students' Mathematical Communication Skills

\begin{tabular}{|c|c|c|}
\hline & Experimentation Class & Control class \\
\hline Average & 0.49 & 0.45 \\
\hline Standard Deviation & 0.17 & 0.27 \\
\hline
\end{tabular}

Based on Table 4.10. it can be seen that the N-Gain index of the mathematical communication ability of the experimental class is 0.49 higher than the $\mathrm{N}-$ Gain index of the control class's connection ability of 0.45 . This shows that the increase in mathematical communication skills of students who are given a Contextual approach is higher than the improvement of mathematical communication skills of students who are given the Ordinary approach. In addition, the standard deviation of the N-Gain index in the experimental class was 0.17 smaller than the standard deviation of the N-Gain index in the control class which was 0.27 .

2) Analysis of Difficulties in Solving Students 'Mathematical Problem-Solving Ability Problems and Students' Mathematical Creative Thinking Abilities in Mathematics

Difficulties in students' creative thinking processes in learning problem based learning while working on problems. To analyze it, some students who represent each category were taken. In the high category, students do not experience significant difficulties in solving the given problem. In the medium category, students have difficulty completing the given questions. In the low category, students have difficulty writing down what is known and asked in the problem, understanding the problem contained in the problem.

The difficulty of students' problem solving processes in learning problem based learning when working on problems. To analyze it, some students who represent each category were taken. In either category, students can easily understand the given problem well. In the sufficient category, students can already understand the problem well, but are still wrong at the final solution. In the less category, students find it very difficult to understand the questions given

\section{Discussion}

a. Improvement of Students' Mathematical Connection Capabilities.

Based on the results of descriptive data analysis, before being given treatment, students in both classes have mathematical connection abilities that are not significantly different. This can be seen from the pretest scores of the experimental and control classes respectively 5.9 and 5.0. After being treated, the connection ability of students who learn with a contextual approach is higher than students who learn with a normal learning approach. This is indicated by the average posttest score of the experimental class that is 8.5 , while in the control class it is 6.7 . The posttest maximum score of students in the two experimental classes did not show any significant differences, where the maximum posttest score of the experimental class and the control class were 11 and 10. Both of these maximum scores were obtained by students who had high KAM. This is clearly acceptable because children who have high KAM can certainly master the new material well and easily. Meanwhile, the minimum posttest scores of the experimental class and control class students were 4 and 3. Both scores were obtained by students who had low KAM. Furthermore, the increase in mathematical connection capabilities that occur in the two classes is also different. After being given treatment, the improvement of students' mathematical connection ability in the 
experimental class is higher than the control class, as indicated by the average N-Gain index of the experimental class and the control class respectively of 0.45 , which is moderate and 0.25 with the category of improvement classified as low.

Based on the results of inferential statistical analysis with the t test, it can be concluded that there is a significant difference in the increase in mathematical connection skills between students taught with contextual approaches and ordinary learning, where the increase in mathematical connection abilities of students taught with contextual approaches is higher than the increase in students' mathematical connection abilities which is taught with the usual learning approach. This is in accordance with the study in chapter II that by learning through the process of guided discovery and carried out gradually, students are able to understand mathematical concepts themselves, especially related to mathematical connections and communication. At the beginning of learning the first meeting in the experimental class students need a long time to follow the stages of mathematical, but students continue to experience progress in getting better in their thought processes. Understanding mathematical problems by simply observing and imagining related images initially feels difficult for students because they are not familiar. Moreover, in making appropriate mathematical models and equations, students need a long time to find it. However, with the guidance of the teacher, most students who are taught with a contextual approach are better able to understand the concepts of the material they are learning and can understand the context of different problems so as to be able to make mathematical connections that are appropriate to the context of the problem. In accordance with Bruner's learning theory that learning discovery provides the best results (Dahar, 1991: 103). In addition, in learning with a contextual approach, high, medium and low ability students can learn together well. Low and medium-ability students are not too difficult to follow the existing learning process, so with the guidance of the teacher they can collaborate with friends with high ability to learn the material assigned. This is consistent with the results of Ferdy Arif Tohopi's research (2015: 2103) that mathematics learning with a contextual learning approach has significantly improved mathematical connection skills in the high, medium and low mathematical ability groups compared to conventional approaches. This finding is also in line with research by Zulkarnain, et al (2016: 11) that the ability of students' mathematical connections through contextual learning approaches has increased significantly compared to conventional learning. Meanwhile, in the control class most students tend to be less able to understand the context of problems with different forms than before, and this has implications for their ability to make appropriate mathematical connections. This is because students learn by observing and understanding existing examples. In addition, learning is dominated by students with high ability, while students with low ability are not able to properly follow the learning process that occurs in their respective groups.

\section{b. Improving Students' Mathematical Communication Skills.}

Based on the results of descriptive data analysis, before being given treatment, students in both classes have mathematical communication skills that are not significantly different. This can be seen from the pretest scores of the experimental and control classes respectively 6.63 and 6.13. After being treated, the communication skills of students who learn with a contextual approach are higher than students who learn with a normal learning approach. This is indicated by the average posttest score of the experimental class that is 11.53 , while in the control class it is 8.6. The maximum posttest scores of students in the two experimental classes showed a significant difference, where the maximum posttest scores of the experimental class and control class were 15 and 11 . Both of these maximum scores were obtained by students who had high KAM. This is clearly acceptable because children who have high KAM can certainly master the new material well and easily. Meanwhile, the posttest minimum score of experimental class students of 7 is quite large compared to the posttest minimum score of control class students which is equal to 4 . Both of these scores are obtained by students who have low KAM. This means that students with low KAM in the class given the Contextual approach have improved mathematical communication skills that are better than the class given the Ordinary learning approach. Furthermore, the improvement in mathematical communication skills that occur in the two classes is also different. After being given treatment, the improvement of students' mathematical communication skills in the experimental class was higher than the control class, as indicated by the average N-Gain index of the experimental class by 0.54 with a moderate increase category and a control class by 0.25 with a relatively low increase category

Based on the results of inferential statistical analysis with the $t$ test, it can be concluded that there is a significant difference in the improvement of mathematical communication skills between students taught with the Contextual approach and ordinary learning, where the improvement in mathematical communication skills of students taught with the Contextual approach is higher than the increase in mathematical communication skills of students which is taught with the usual learning approach. This is in accordance with the study in chapter II that by learning through contextual learning and done in stages, students are able to understand mathematical concepts themselves, especially related to mathematical connections. At the beginning of learning the first meeting in the experimental class students need a long time to follow the stages of mathematical, but students continue to experience progress in getting better in their thought processes. Understanding mathematical problems by simply observing and imagining related images initially feels difficult for students because they are not familiar. Moreover, in making appropriate mathematical models and equations, students need a long time to find it. However, with the 
guidance of the teacher, most students who are taught with a Contextual approach are better able to understand the concepts of the material they are learning and can understand the context of different problems so as to be able to communicate in accordance with the context of the problem. In accordance with Bruner's learning theory that learning discovery provides the best results (Dahar, 1991: 103). In addition, in learning with a contextual approach, high, medium and low ability students can learn together well. Low and medium-ability students are not too difficult to follow the existing learning process, so with the guidance of the teacher they can collaborate with friends with high ability to learn the material assigned. This is consistent with the results of research by Hafijiani Eka Putri (2006: 127) that the mathematical communication skills of students whose learning uses contextual approaches are better than students who use conventional approaches. This is possible because learning by using this contextual approach is a learning approach that emphasizes more on the activeness of students to be able to reconstruct their own knowledge, through real problems that are given and of course these problems are closely related to the lives of the students themselves. Meanwhile, in the control class most students tend to be less able to understand the context of different form of problems than before, and this has implications for their ability to make appropriate mathematical communication. This is because students learn by observing and understanding existing examples. In addition, learning is dominated by students with high ability, while students with low ability are not able to properly follow the learning process that occurs in their respective groups. One reason is because the learning process is not done in stages and is complex.

\section{b. Interaction between Learning Approach and KAM on Improving Students' Mathematical} Connection Ability.

Based on the results of descriptive analysis, the increase in the ability of students' mathematical connections both low, medium and high initial ability in the experimental class is all higher than the control class at all levels of the initial ability. This can be seen from the average N-Gain index of mathematical connection ability in the experimental class at the level of initial mathematical ability of low, medium and high respectively 0.27 classified as low, 0.42 is classified as moderate and 0.71 is classified as high. While in the average N-Gain in the control class at the level of initial mathematical ability is low, medium and high respectively 0.16 classified as low, 0.23 is classified as low and 0.41 is classified as moderate.

Based on the results of inferential statistical analysis with the two-way ANAVA Test, it can be concluded that there is no significant interaction between the learning approach and the initial mathematical ability to improve students' mathematical connection abilities. This is supported by the results of Silalahi's study (2015) which concluded the same thing. This means that the learning approach does not significantly influence the improvement of mathematical connection abilities at the level of initial mathematical abilities that are low, medium or high. In accordance with the opinion of Kerlinger (1990: 399) that "Interaction occurs when an independent variable has different effects on a dependent variable at various levels of another independent variable". It can also be said that only the learning approach has a significant influence on improving students' mathematical connection abilities. While the initial mathematical ability factor shows that students in the experimental class and in the control class have increased abilities according to the level of initial abilities possessed respectively. In this case, it can be concluded in general that the increase in the mathematical connection ability of students taught with a contextual approach is higher than students who are taught with an ordinary learning approach at all levels of initial mathematical ability.

c. Interaction between Learning Approach and KAM on Improving Student Communication Ability.

Based on the results of descriptive analysis, the increase in mathematical communication skills of students who have low, medium and high initial abilities in the experimental class are all higher than those of the control class. This can be seen from the average N-Gain index of mathematical communication skills in the experimental class at the level of initial mathematical ability low, medium and high respectively 0.42 classified as moderate, 0.52 classified as moderate, and 0.72 classified as high. While the average N-Gain in the control class at the level of initial mathematical ability is low, medium and high respectively 0.18 is classified as low, 0.25 is classified as low and 0.35 is classified as moderate.

Based on the results of inferential statistical analysis with the two-way ANAVA Test, it can be concluded that there is no significant interaction between the learning approach and the initial mathematical ability to improve students' mathematical communication. This also means that the learning approach does not significantly influence the improvement of students' mathematical communication at low, medium or high levels of initial mathematical ability. Early mathematical ability factor shows that the increase in students' mathematical communication that occurs in the experimental class and in the control class is in accordance with their respective initial ability levels. Thus, learning approaches play an important role in improving students' mathematical communication. This is in line with Ritonga's research (2017: 172) which concludes that "KAM and learning factors do not have a significant effect on improving students' mathematical communication skills". In this case, it can be concluded in general that the improvement of students' mathematical communication taught with a contextual approach is higher than students who are taught with a normal learning approach at all levels of early mathematical ability. As Glass \& Hopkins (2008: 486-487) said, "The absence of interaction is the statistical justification for generalizability". 


\section{Conclusion}

1. Increased mathematical connection ability of students who get contextual learning is higher than students who get ordinary learning.

2. Improvement of mathematical communication skills of students who get contextual learning is higher than students who get ordinary learning.

3. There is no interaction between the learning approach and initial mathematical ability to improve students' mathematical connection abilities.

4. There is no interaction between learning approaches and initial mathematical ability to improve students' mathematical communication skills

\section{REFERENCES}

Ansari, I. Bansu. (2009). Komunikasi Matematika Konsep dan Aplikasi. Banda Aceh: Yayasan Pena.

Dahar, Ratwa Wilis. (2012). Teori-teori Belajar. Jakarta: Erlangga

Ferdy Arif Tohopi. (2015). Pengaruh Penerapan Pendekatan Pembelajaran Kontekstual (CTL) Terhadap Kemampuan Koneksi Matematis Siswa Kelas XI SMA Terpadu Wira Bhakti Pada Pokok Bahasan Turunan. Gorontallo : Tesis PPs Universitas Negeri Gorontallo. Tidak diterbitkan.

Glass Gene V \& Hopkins Kenneth D. (2008). Statistical Methods In Education and Psycholohy. Englewood Cliffs. NJ: Prentice-Hall.

Hariwijaya. (2013). Meningkatkan Kecerdasan Matematika. Yogyakarta: Tugupublisher.

Hafijiani Eka Putri (2006). Pembelajaran Kontekstual Dalam Upaya Meningkatkan Kemampuan Komunikasi dan Koneksi Matematik Siswa SMP. Bandung. Tesis PPs UPI. Tidak diterbitkan.

Kerlinger, F.N. (1990). Asas-asas Penelitian Behavioral, Penerjemah : Landung R Situmorang, Yogyakarta : Gadjah Mada University Press

N. Kusumawati, dkk. (2012). Pembelajaran Program Linear Berkarateristik Kewirausahaan Untuk Meningkatkan Kemampuan Komunikasi Matematik. Unnes Journal Of Mathematics Education Research. Universitas Negeri Semarang.

Nurhadi. (2014). Pembelajaran Kontekstual dan Penerapannya dalam KBK. Jakarta: Grasindo.

Ontario Ministry of Education. (2006). A guide to effective instruction in mathematics, Kindergarten to grade 6: Volume 2 - Problem solving and communication. Toronto, ON: Queen's Printer for Ontario.

Polla, G. (1999), Efforts to Increase Mathematics for all through Communication in Mathematics Learning. [Online]. Tersedia: http://72.14.203.104/search? q=eache:IVSmQCvwl-4J:www.icmcorganiser.dk/dg03/Gerardus.doc + gerardus + polla\%2Bin + mathematics $\& \mathrm{hl}=\mathrm{id} \& \mathrm{gl}=\mathrm{id} \& \mathrm{ct}=\mathrm{clnk} \& \mathrm{~cd}=5$

Ritonga Fauziawati (2017). Peningkatan Kemampuan Komunikasi Matematis dan Self-Efficacy Siswa Menggunakan Pembelajaran Contextual Teaching and Learning (CTL) Berbantuan Virtual Manipulative di SMP Negeri 2 Rantau Selatan. Tesis PPs UNIMED. Tidak Diterbitkan.

Ruspiani. (2000). Kemampuan Siswa dalam Melakukan Koneksi Matematik. Bandung : Tesis PPs UPI. Tidak diterbitkan

Silalahi, Taruli Marito (2015). Peningkatan Kemampuan Koneksi Matematik dan Sikap Positif Siswa Dengan Pembelajaran Kontekstual Pada Siswa SMK Pelayaran Samudera Indonesia Medan. Tesis PPs UNIMED. Tidak Diterbitkan

Siregar Eveline dan Hartini Nara, (2014). Teori Belajar dan Pembelajaran. Bogor : Ghalia Indonesia. Suriasumantri, Jujun S. (2012). Filsafat Ilmu Sebuah Pengantar Populer. Jakarta: Pustaka Sinar Harapan Zulkarnain dkk (2016). Peningkatan Kemampuan Komunikasi dan Koneksi Matematis Siswa Melalui Pendekatan Pembelajaran Kontekstual di Sekolah Menengah Atas. Jurnal Pendidikan dan Pembelajaran Khatulistiwa. Vol 5, No.5. 